\title{
HUBUNGAN KOMITMEN ORGANISASI DAN IKLIM ORGANISASI DENGAN KEPUASAN KERJA KARYAWAN RUMAH SAKIT SWASTA ISLAM MALANG
}

\author{
Nurul Asfiah \\ Fakultas Ekonomi dan Bisnis Universitas Muhammadiyah Malang \\ E-mail: asfi.1918@gmail.com
}

\begin{abstract}
The aims of research are to know the condition and to examine the relationship between organizational commitment and climate to the employee' job satisfactions. The research was conducted in Islamic Private Hospital Malang and include 140 peoples as respondents. Questionnaires used as an instrument for collecting data. The analyses method uses Rank scale and product moment correlation. The results of research show that the organizational commitment is in good conditions as well as organizational climate. Whereas, the conditions of employee' job satisfaction is in the high level satisfied. Based on the product moment show that the relationship between both organizational commitment and climate to the employee' job satisfaction are in the strong level. It means that all employees in Islamic Private Hospital are having strong organizational commitment and feeling satisfaction when they are working. It is also the organizational climate, it supports to make employee enjoy their working.
\end{abstract}

Keywords: organizational commitment and organizational climate, employee' job satisfaction, Islamic Private Hospital Malang.

\section{PENDAHULUAN}

Efektivitas organisasi sangat ditentukan oleh komitmen orang-orang yang dimilikinya. Komitmen ini seringkali dituntut oleh organisasi maupun pemimpin yang ada terhadap orang-orang yang menjadi anggota organisasi. Orang-orang telah memberikan pikiran, tenaga, waktu, dan seluruh upayanya untuk mendukung tercapainya tujuan organisasi, sebagaimana ditetapkan sebelumnya. Pencapaian tujuan organisasi tentu menjadi kewajiban bagi orang-orang tersebut, sebagai sebuah tanggung jawab atas standar kerja yang telah ditentukan. Sementara itu komitmen organisasional ini harus didukung oleh tata nilai yang dipahami dan dikembangkan oleh organisasi tersebut. Tata nilai ini dalam konteks organisasional akan tercermin dalam budaya organisasi, yang disepakati bersama, dan selanjutnya akan memberikan dampak terhadap efektivitas organisasi (Schein, 1991).

Pada sisi lain, organisasi yang telah menjadi tempat mengabdi bagi orang-orang atau karyawan tersebut, haruslah mampu mengimbangi kewajiban dan tanggung jawab yang telah diterimanya dari karyawan dengan upaya-upaya organisasional untuk menciptakan tempat kerja yang nyaman. Hal ini perlu dilakukan untuk mencapai saling kesepahaman dan kesesuaian dalam dunia kerja, untuk mendapat hasil terbaik dengan adanya prestasi yang baik dari karyawan tersebut. Dalam hal ini Rensis Likert mengembangkan instrumen klasik yang berfokus pada gaya manajemen yang diterapkan pada organisasi. Likert menyimpulkan bahwa iklim yang lebih berorientasi manusia menghasilkan tingkat prestasi yang lebih tinggi dan kepuasan kerja yang lebih besar.

Sebagai wadah layanan kesehatan masyarakat luas, rumah sakit swasta di Malang telah berkembang dengan sangat pesat, dan telah menjadi sebuah lembaga sosial 'profit'. Sebagai lembaga sosial 'profit', maka karyawan yang bekerja pada umumnya dibentuk atau dituntut dapat bekerja optimal akan tetapi dengan 'diharapkan' tanpa menuntut imbalan semata.

Secara umum karyawan dituntut untuk menetapi komitmen atas pekerjaan yang harus dilakukan semata-mata karena menjalankan ibadah (sebagai konsep hidup beragama), yang bahkan dikemas dengan slogan organisasi Layananku Ibadahku. 
Slogan demikian digunakan oleh rumah sakit yang berbasis Islam untuk mendapatkan kepercayaan yang luas dari masyarakat.

Karyawan akan mengeluarkan upaya dan usaha yang optimal dengan semangat kerja yang tinggi, bila hak-hak yang dituntutnya dapat dipenuhi oleh organisasi. Usaha yang optimal ini akan berdampak pada rasa senang bagi karyawan tersebut terhadap pekerjaan dan organisasinya mengeluarkan tenaga, pikiran, waktu dan upaya-upaya yang optimal.

Dengan demikian rasa senang dalam bekerja ini akan menjadikan karyawan menjadi termotivasi untuk mencapai kinerja sebagaimana yang dituntut oleh organisasi. Kondisi karayawan yang termotivasi maupun semangat dalam bekerja ini tentulah sangat menguntungkan bagi organisasi. Oleh karena itu, organisasi perlu menciptakan kondisi dan kepemimpinan yang menyenangkan bagi karyawan yang ada.

Sebuah hasil penelitian yang telah dilakukan oleh Yudhi (2006) di Universitas Muhammadiyah Surakarta, dengan populasi seluruh karyawan tetap (dosen dan tenaga administratif) dengan responden sebanyak 622 orang menemukan bahwa hubungan antara komitmen organisasi dan iklim organisasi dengan kepuasan kerja karyawan adalah kuat. Penelitian ini mengambil sampel sebanyak 300 lakilaki maupun perempuan, dengan teknik random sampling, dengan menggunakan analisis regressi. Selain itu ditemukan perbedaan yang sangat signifikan antara komitmen organisasi, iklim organisasi dan kepuasan kerja di masing-masing unit organisasi.

Selain penelitian di atas, hasil penelitian yang dilakukan oleh Michael D. Thompson juga mencoba untuk menghubungkan antara iklim organisasional dengan kepuasan kerja karyawan. Adapun variabel independen pada penelitian ini adalah struktural, sumber daya manusia, politik dan simbolik dan kepuasan kerja bertindak sebagai variabel dependen. Obyek penelitian adalah tenaga administratif dengan 280 quesioner yang disebar, dan kembali sebanyak 261. Teknik analisis yang digunakan adalah MANOVA, dan hasilnya adalah ada perbedaan yang signifikan kepuasan kerja di setiap tingkatan jabatan yang ada.

Penelitian ini dilakukan tidak di perguruan tinggi, yang unsur utama produknya adalah pendidikan, akan tetapi di rumah sakit, yang memberikan layanan kepada masyarakat luas. Hal utama yang dilakukan pada penelitian ini adalah mencoba mencari permasalah dan memecahkannya berkaitan dengan komitmen karyawan terhadap organisasi dan iklim organisasional yang harus diciptakan oleh organisasi/pemimpin sehingga terbentuk atau tercipta suasana yang menyenangkan, dengan kata lain kepuasan kerja karyawan terpenuhi.

\section{TINJAUAN PUSTAKA}

Perilaku yang terpola yang menjadi tindakantindakan reflek dan berulang akan memberikan dampak secara langsung bagi organisasi yang bersangkutan. Tindakan yang selaras dan sesuai dengan tata nilai dan kepercayaan yang ada dalam perusahaan akan berdampak pada keefektifan organisasi. Demikian pula sebaliknya, tindakantindakan yang tidak selaras dan tidak sesuai dengan tata nilai yang dianut maupun kepercayaan organisasi, akan mengakibatkan ketidakefektifan organisasi, sebagaimana yang diungkapkan Schein (1991).

Gambar berikut menjelaskan hubungan yang ada antara nilai-kepercayaan, kebijakan-praktik organisasional dengan efektivitas serta dengan lingkungan yang ada. Efektivitas merupakan fungsi nilai dan kepercayaan dari anggota (karyawan) yang ada dalam organisasi sebagaimana pada gambar di bawah:

Budaya organisasi yang terbentuk dalam sebuah organisasi, akan direfleksikan ke dalam cara organisasi tersebut dalam menyelesaikan berbagai persoalan, baik dalam beradaptasi dengan perubahan lingkungan, maupun bagaimana berintegrasi secara internal, sehingga senantiasa akan tercapai keselarasan dan keseimbangan dalam berbagai konflik internal.

Setiap organisasi mempunyai iklim atau kepribadiannya atau tabiatnya sendiri yang membedakannya dari organisasi-organisasi lainnya dan yang mempengaruhi perilaku anggotaanggotanya. Oleh karena itu manajemen harus berusaha menciptakan suatu iklim yang memungkinkan tercapainya tujuan organisasi dan pada saat yang sama memenuhi kebutuhan-kebutuhan psikologis dan social dari pegawaipegawainya (Moekijat, 1988:97). 


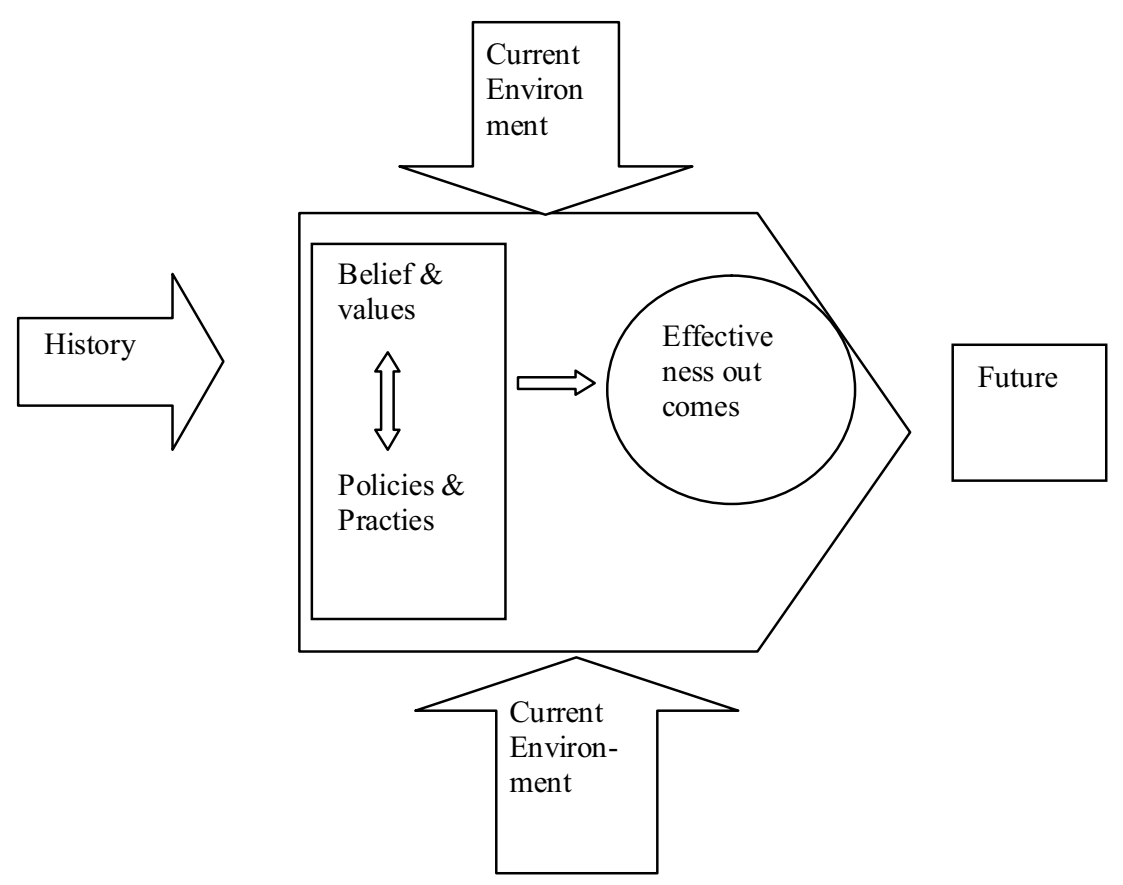

Gambar 1. Hubungan lingkungan, sejarah, efektivitas organisasi dengan masa depan

Ada banyak ciri yang membedakan organisasi satu dengan organisasi yang lain dan memberi kepadanya suatu tabiat khusus. Salah satunya adalah tujuan-tujuannya. Kenyataan bahwa organisasi-organisasi pemerintah, organisasi-organisasi amal, organisasi-organisasi pendidikan dan organisasiorganisasi yang mencari keuntungan mempunyai tujuan-tujuan yang berlainan mengakibatkan iklimiklim yang berlainan dalam organisasi tersebut.

Iklim adalah suasana di dalam organisasi, yaitu perasaan dan dorongan hati orang-orang didalamnya. Inilah anggapan mereka tentang apa yang patut dikerjakan disana. Karena perasaan dan sikap para pegawai akan dengan jelas berpengaruh terhadap cara mereka melakukan pekerjaan, mereka merupakan bagian penganalisisan organisasi yang penting (Cushway \& Lodge, 1995:25).

Iklim organisasi adalah lingkungan manusia di dalam mana para pegawai organisasi melakukan pekerjaan mereka yang dipengaruhi oleh hampir semua hal yang terjadi dalam suatu organisasi. Iklim adalah konsep sistem yang dinamis yang mencerminkan keseluruhan gaya hidup suatu organisasi (Davis \& Newstrom, 1989:25).

Selanjutnya Likert dalam Davis dan Newstrom (1989:24) mengenalkan indikator iklim organisasi, yaitu: Komunikasi, Tanggung jawab,
Kepemimpinan, Kesempatan, Imbalan yang adil, dan Kepercayaan. Rensis Likert mengembangkan instrumen klasik yang berfokus pada gaya manajemen yang diterapkan pada organisasi. Likert menyimpulkan bahwa iklim yang lebih berorientasi manusia menghasilkan tingkat prestasi yang lebih tinggi dan kepuasan kerja yang lebih besar. Untuk menciptakan iklim organisasi yang sehat maka harus didukung dengan faktor-faktor yang ada diatas dan dapat direalisasikan pada organisasi, yang menimbulkan suatu situasi atau suasana yang dapat mempengaruhi iklim organisasi tersebut. Faktor-faktor inilah yang membentuk iklim dan iklim tersebut akan berbeda suasananya antara organisasi satu dengan yang lainnya.

Selanjutnya Porter dalam penelitiannya menyatakan bahwa komitmen organisasi didefinisikan sebagai pengidentifikasian dan keterlibatan seorang individu terhadap organisasi tertentu(Meyer,1989). Mowday, Porter dan Steers (dalam Meyer, 1993) mendefinisikan komitmen organisasi sejalan dengan pendapat Porter, yaitu sebagai sifat hubungan antara pekerja dan organisasi. Individu yang mempunyai komitmen tinggi terhadap organisasi dapat dilihat dari: (1) Keinginan kuatuntuk tetap menjadi anggota organisasi tersebut ; (2) Kesediaan berusaha sebaik mungkin demi kepentingan organisasi 
tersebut ; dan (3) Kepercayaan akan dan penerimaan yang kuat terhadap nilai-nilai dan tujuan organisasi.

Sedangkan Howell dan Dipboye (1986) dalam bukunya Ashar Sunyoto Munandar, memandang kepuasan kerja sebagai hasil keseluruhan dari derajat rasa suka atau tidak sukanya tenaga kerja terhadap berbagai aspek dari pekerjaannya. Dengan kata lain kepuasan kerja mencerminkan sikap tenaga kerja terhadap pekerjaannya.

Kepuasan kerja adalah suatu keadaan bersegi banyak, beberapa segi lebih memuaskan daripada yang lain. Kepuasan kerja biasanya hanya melukiskan suatu rerata hasil dari perbandingan beberapa keadaan pada suatu saat tertentu. Kepuasan kerja muncul bila keuntungan yang dirasakan dari pekerjaannya melampaui biaya marjinal yang dikeluarkan, yang oleh karyawan tersebut dianggap cukup memadai (Fraser, 1992:43).

Robbins (1996: 181) memandang kepuasan kerja sebagai sikap umum seseorang individu terhadap pekerjaannya. Setiap karyawan memiliki perasaan puas dan tidak puas terhadap pekerjaannya. Beberapa indikator dari kepuasan kerja adalah pekerjaan yang menantang yang diberikan perusahaan, imbalan yang setimpal, kondisi lingkungan kerja dalam perusahaan serta hubungan dengan rekan kerja.

Kepuasan kerja (job satisfaction) adalah keadaan emosional yang menyenangkan atau tidak menyenangkan dengan mana karyawan memandang pekerjaan mereka. Kepuasan kerja mencerminkan perasaan seseorang terhadap pekerjaannya. Ini nampak dalam sikap positif karyawan terhadap pekerjaan dan segala sesuatu yang dihadapi di lingkungan kerjanya (Handoko, 2000:193). Barbash (1974) berpendapat, bahwa kepuasan kerja adalah hal yang sangat subjektif bagi setiap orang dan pencarian kepuasan kerja bukanlah suatu kecenderungan pekerja semata-mata, melainkan terutama suatu kebiasaan yang dimungkinkan dari atas oleh para teknokrat dan manajemen yang agak liberal (Fraser, 1992:48).

Dari beberapa pendapat diatas dapat disimpulkan bahwa kepuasan kerja adalah cara pandang karyawan terhadap menyenangkan atau tidak menyenangkan segala sesuatu yang berkaitan dengan pekerjaannya. Berbagai aspek dan segi dari pekerjaan dapat mempengaruhi kepuasan kerja oleh karena itu kepuasan yang dialami tiap karyawan tidaklah sama.
Kondisi-kondisi seperti ini mengharuskan manajemen untuk pandai-pandai membaca kebutuhan karyawannya agar mencapai kepuasan kerja. Adapun faktor-faktor yang mempengaruhi kepuasan kerja seseorang yang menurut Munandar (2001) sebagai berikut:Pertama, Keragaman keterampilan.Banyak ragam keterampilan yang diperlukan untuk melakukan pekerjaan. Makin banyak ragam keterampilan yang digunakan, makin kurang membosankan pekerjaan.

Kedua, jati diri tugas (task identity). Sejauh mana tugas merupakan suatu kegiatan keseluruhan yang berarti. Tugas yang dirasakan sebagai bagian dari pekerjaan yang lebih besar yang dirasakan tidak merupakan suatu kelengkapan tersendiri akan menimbulkan rasa tidak puas.Ketiga, tugas yang penting. Jika pekerjaan atau tugas yang dipercayakan kepadanya mempunyai nilai penting dan berarti bagi karyawan maka ia akan semakin memiliki kepuasan kerja.

Kelima, otonomi. Pekerjaan yang memberikan kebebasan, ketidaktergantungan dan peluang mengambil keputusan akan lebih cepat menimbulkan kepuasan kerja.Kelima, iklim organisasi. Iklim organisasi menunjukan keadaan lingkungan dan cara hidup suatu organisasi. Iklim dapat mempengaruhi motivasi, prestasi dan kepuasan kerja.

Tidak dapat dipungkiri bahwa segala sesuatu yang ada di sekitar kita akan mempengaruhi kita baik secara langsung maupun tidak langsung di manapun kita berada baik di rumah, sekolah, kantor ataupun tempat lainnya. Begitu pula di dalam perusahaan, berbagai aspek di dalam suatu perusahaan atau organisasi sekecil apapun pasti mempunyai pengaruh baik itu positif ataupun negatifterhadap aspek lainnya. Salah satunya ialah iklim organisasi yang sebagaimana telah dijelaskan sebelumnya bahwa iklim organisasi adalah suasana lingkungan dimana karyawan melakukan pekerjaan mereka. Kondisi inilah yang nantinya akan memunculkan suatu kepuasan atau tidak kepuasan pada karyawan.

Dari pernyataan diatas sudah jelas bahwa kaitan dan hubungan antara iklim organisasi dengan kepuasan kerja sangatlah erat dan tidak dapat dihiraukan begitu saja. Kondisi iklim organisasi berperan terhadap kepuasan kerja seorang karyawan dalam pekerjaannya.

Kerangka pikir merupakan model konseptual yang menjelaskan hubungan faktor Iklim organisasi 
dan komitmen organisasi serta kepuasan karyawan. Berdasarkan teori-teori pada landasan teori yang telah dikemukakan, maka dibuatlah kerangka pemikiran untuk memudahkan pemahaman konsep yang digunakan dalam penelitian ini. Adapun kerangka pikir tersebut dapat digambarkan pada gambar 2 .

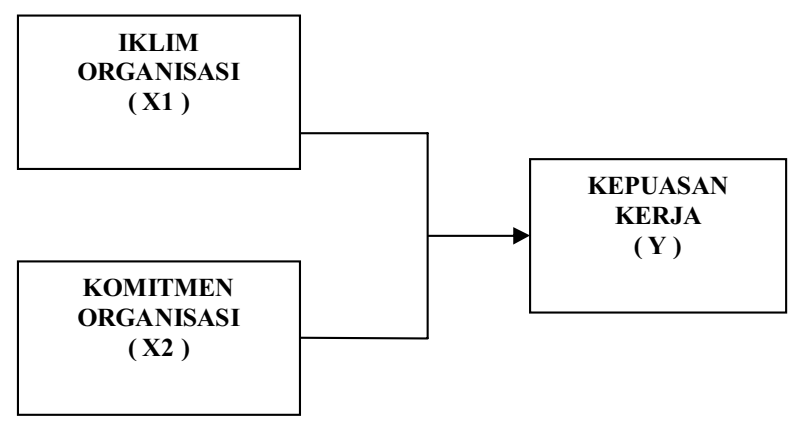

Gambar 2 Hubungan Iklim dan Komitmen Organisasi terhadap Kepuasan Kerja

\section{METODE PENELITIAN}

Data pada penelitian ini adalah data primer, yang diambil secara langsung dari obyek penelitian. Data ini dikumpulkan melalui penyebaran angket atau kuisioner, dan wawancara langsung yang mendalam dengan pihak-pihak terkait.Selain dari data primer, penelitian ini juga menggunakan data sekunder, yaitu data yang telah diolah pihak lain, dan yang dikumpulkan melalui teknik dokumentasi maupun dengan melakukan observasi secara langsung dengan membuat catatan-catatan yang perlu. Penelitian ini merupakan penelitian deskriprif kualitatif, dengan menggunakan variable Iklim organisasi (X1) dihubungkan dengan Kepuasan kerja dan bersama-sama dengan Komitmen organisasi (X2) akan dilihat hubungannya dengan Kepuasan kerja (Y).

Kepuasan kerja (Y) adalah suatu sikap umum (kognitif, afektif, dan konatif) seorang inividu terhadap pekerjaannya yang meliputi: gaji / pembayaran, work it self, promosi, supervisi dan rekan kerja. Iklim organisasi (X1) adalah sifat lingkungan kerja atau lingkungan psikologis dalam organisasi yang dirasakan oleh para pekerja atau anggota organisasi dan dianggap dapat mempengaruhi sikap dan prilaku pekerja terhadap pekerjaannya. Faktor-faktornya adalah konformitas, tangguangjawab, standart, penghargaan, kejelasan organisasi, dan dukungan kepemimpinan. Komitmen organisasi (X2) didefinisikan sebagai komitmen affective attachment terhadap organisasi, komitmen sebagai persive cost yang berhubungan dengan tetap tinggal dalam organisasi, dan komitmen sebagai suatu keyakinan untuk mengeluarkan upaya yang sungguh-sungguh dalam bekerja.

Populasi dan sampel pada penelitian ini adalah karyawan tetap, yang berdasarkan pada data yang ada, jumlah tenaga kerja tetap berjumlah 140 orang, yang diambil dua Rumah Sakit Islam di kota Malang. Responden tersebut adalah tenaga medis, para-medis, serta tenaga administratif. Selain kriteria tersebut, maka setiap pimpinan, seluruh level organisasi,oleh karena itu teknik sampling yang digunakan adalah purposive sampling.

Pengukuran variabel penelitian ini menggunakan skala Likert, menurut Kinnear (1998) dalam Umar. Skala Likert ini berhubungan dengan pernyataan tentang sikap seseorang terhadap sesuatu, dengan responsi setuju atau tidak setuju, senang atau tidak senang dan baik atau tidak baik.

Skala ordinal berbentuk verbal dalam jumlah kategori tertentu bisa 5 atau 7 agar dapat menampung kategori netral (Umar, 1998: 133). Adapun kuisioner pada penelitian ini menggunakan 5 kategori, dengan pilihan jawaban 1 sampai 5, yang menggambarkan pendapat responden mulai sangat tidak setuju sampai sangat setuju. Selanjutnya dilakukan uji validitas maupun uji Sreliabilitas. Selanjutnya data tersebut akan diuji dengan menggunakan uji korelasi product moment, untuk menentukan kuat tidaknya hubungan antara komitmen organisasi dan iklim organisasi dengan kepuasan kerja karyawan.

\section{HASIL PENELITIANDANPEMBAHASAN}

Berdasarkan pada hasil pengujian terhadap item-item kuisioner, diperoleh bahwa seluruh nilai dari pengujian ini untuk masing-masing item adalah di atas nilai kritis 0,250 dengan taraf signifikan 0,05 (5\%). Artinya bahwa item-item untuk komitmen organisasional, iklim organisasional, maupun itemitem kepuasan kerja karyawan tersebut adalah valid, atau instrumen yang digunakan adalah sah. Sedangkan untuk uji reliabilitas terhadap semua variabel yang digunakan pada penelitian ini juga reliabel atau dapat dipertanggungjawabkan dan layak di- 
gunakan, karena nilai yang diperoleh berada di atas 0,6 pada nilai alpha cronbach.

Skala kriteria yang didapat dari perhitungan dengan rentang skala menunjukkan bahwa rentang kriteria untuk masing masing variabel adalah sebesar 112, dan angka terendah dari rentang kriteria tersebut adalah $140(140 \times 1)$. Dengan kategori pilihan 1 sampai 5, maka rentang kriteria tertinggi adalah $699(140 \times 5)$. Adapun hasil penelitian ini menjelaskan bahwa untuk variabel komitmen organisasional (X2) dan iklim organisasi (X1) adalah baik, dimana iklim organisasional ditampakkan oleh nilai kriteria sebesar 577, sedangkan komitmen organisasional sebesar 567. Sedangkan untuk variabel kepuasan kerja karyawan digambarkan puas, yang berada pada rentang kriteria 549 .

Adapun hasil uji hubungan dengan menggunakan korelasi product moment. Dari hasil penelitian didapatkan, bahwa hubungan antara komitmen organisasional (X2) dengan kepuasan kerja karyawan adalah menunjukkan kuat, dengan nilai sebesar 0,67 . Sedangkan dari hasil penelitian untuk hubungan variabel iklim organisasi (X1) dengan kepuasan kerja karyawan menunjukkan nilai sebesar 0,68 . Artinya hubungan antara iklim organisasional (X1) dengan kepuasan kerja karyawan juga kuat. Hal ini karena kedua variabel ini menunjukkan nilai yang mendekati 1.

Berdasarkan hasil analisis data tersebut menunjukkan, bahwa iklim organisasional (X1) yang ada di rumah sakit Islam di Malang tersebut berada pada kondisi baik. Hal ini berarti bahwa kondisi rumah sakit sebagai layanan kesehatan bagi masyarakat luas yang diciptakan pada rumah sakit Islam adalah baik pada yang bersifat fisik maupun non fisik. Hal ini menunjukkan adanya konformitas, tanggungjawab, standard pekerjaan yang jelas, penghargaan yang baik, kejelasan organisasi, dan dukungan kepemimpinan yang baik pula, sehingga tercipta situasi yang kondusif dalam bekerja.

Sedangkan analisis data untuk variabel komitmen organisasional(X2) juga menunjukkan adanya kondisi yang baik pula. Hal ini menunjukkan, bahwa karyawan di rumah sakit Islam tersebut seperti komitmen affective terhadap organisasi, yang berarti bahwa karyawan tersebut memang tertarik terhadap pekerjaannya di rumah sakit tersebut, dan mereka sangat menginginkan pekerjaan tersebut.
Demikian juga komitmen sebagai persive cost, yang menunjukkan bahwa karyawan ingin tetap tinggal dalam organisasi karena kalau meninggalkan organisasi ada nilai atau biaya kesempatan yang hilang. Adapun yang terakhir adalah komitmen normatif sebagai suatu keyakinan bahwa dirinya harus bertahan karena nilai-nilai yang berlaku sesuai dengan dirinya dan berupaya untuk mengeluarkan sungguh-sungguh dalam bekerja.

Demikian pula hasil analisis data terhadap variabel kepuasan kerja karyawan menunjukkan bahwa karyawan rumah sakit islam di Malang ini adalah puas dalam bekerja. Berarti bahwa gaji atau pembayaran, work it self, promosi, supervisi dan rekan kerja di rumah sakit islam ini membuat para karyawan tersebut merasa nyaman.

Hal ini ditunjukkan dengan sikap umum seperti kognitif, afektif, dan konatif dari seorang individu terhadap pekerjaannya. Artinya mereka berpikir, merasa maupun berperilaku dengan nyaman dalam rumah sakit tersebut, baik karena pekerjaan itu sendiri, lingkungan maupun teman sejawat.

\section{SIMPULAN}

Hasil analisis data pada penelitian ini menunjukkan adanya iklim organisasi dan komitmen organisasional yang baik di Rumah Sakit Islam di Malang. Hal tersebut ditunjukkan adanya keharmonisan dan kesesuaian antara tuntutan organisasi melalui nilai-nilai yang dituntut dari karyawan dengan apa yang diinginkan oleh karyawan. Di satu sisi karyawan senang dengan pekerjaan dan tempat mereka bekerja, sedangkan disisi lain pemimpin dan organisasi juga mampu memberikan apa yang dibutuhkan oleh karyawan, sekaligus mensinkronkan dengan tujuan organisasi yang harus dicapai.

Keharmonisan dalam organisasi ini akan mampu mewujudkan kepuasan kerja karyawan, dengan menunjukkan semangat kerja yang baik. Hal ini ditunjukkan oleh sikap umum seperti kognitif, afektif, dan konatif karyawan terhadap pekerjaannya, baik dalam berpikir, merasa maupun dalam berperilaku.

Saran yang diajukan berdasarkan dari hasil penelitian ini adalah:pertama, Rumah Sakit Islam di Malang perlu mempertahankan keharmonisan dalam organisasi melalui kesinkronan dan kese- 
suaian antara nilai-nilai dan tuntutan organisasi dan perilaku pemimpin dengan kebutuhan dan tuntutan karyawan, sehingga senantiasa akan terjaga iklim organisasi dan komitmen organisasional serta akan menjaga rasa puas bagi karyawan. Kondisi tersebut perlu dijaga dan dipertahankan secara terusmenerus. Kedua, penelitian dapat dilanjutkan dengan penelitian replika, maupun mengembangkan hasil dari penelitian ini, dengan analisis yang lebih mendalam.

\section{DAFTAR PUSTAKA}

As'ad, Moch.1995.Psikologi Industri.Edisi Keempat, Penerbit Liberty, Yogyakarta.

Barbash. 1994. Work Performance and Job Satisfaction. Allyn and Bacon. Inc. Boston.

Cushway \& Lodge. 1999. Perilaku dan Desain Organisasi.(Alih Bahasa: Tjipto Wardoyo). Penerbit Elex Media Komputindo Kelompok Gramedia. Jakarta

Davis, Keith \& J.W. Newstrom.1992.Perilaku Dalam Organisasi. Terjemahan, PT. Erlangga, Jakarta.

Fraser. 1992. Perilaku Konsumen dan Strategi Pemasaran. Penerbit Prehallindo. Jakarta.

Gibson, James L., John M. Ivancevich, James H. Donelly, Jr., 1996. Organisasi; Perilaku, Struktur, Proses.edisi kedelapan., Terjemahan, Penerbit Binarupa Aksara. Jakarta.

Handoko T. Hani. 2000. Manajemen Personalia dan Sumberdaya Manusia. Edisi II. Cetakan Keempat Belas. Penerbit BPFE. Yogyakarta.
Kreitner.R \& Kinicki.A.2001. Perilaku Organisasi. Terjemahan, Penerbit Salemba Empat.

Mayer, John P.1989. Organizational Commitment and Job Performance: It's The Nature of The Commitment that Counts. Journal of Applier Psychology, vol. 74, 152-156.

Moekijat. 1988. Pengembangan Organisasi. PT. Rosda Karya. Bandung.

Munandar, Ashar. 2001. Psikologi Industri dan Organisasi. Penerbit Universitas Indonesia (UI-Press 2001). Jakarta

Pangestu S., Djarwanto. 1985.Statistik Induktif. Edisi Keempat, Penerbit BPFE, Yogyakarta.

Robbins, Stephen P. 1996. Organizational Behavior. (Hadyana Pujaatmaka, Trans). Penerbit PT Bhuana Ilmu Populer. Jakarta.

Robbins, Stephen P. 2003.Perilaku Organisasi. Jilid Satu, Penerbit PT. Indeks, Jakarta.

Schein, Edgar H. 1991. Organizational Culture and Leadership. Oxford Jossey Bass Publisher. San Fransisco.

Thompson, Michael D.2006.Organizational Climate Perception and Job Element Satisfaction: A Multy-Frame Aplication in a Higher Education Setting, Journal, Internet. Umar, Husein. 1998.Riset Sumber Daya Manusia Dalam Organisasi. Penerbit PT. Gramedia Pustaka Utama, Jakarta.

Yudhi, Satria R.A ; 2006, Hubungan antara Komitmen Organisasi dan Iklim Organisasi dengan Kepuasan Kerja Karyawan Universitas Muhammadiyah Surakarta, Jurnal, Internet. 